\title{
Modulation of Neuromuscular Transmission by Conventional and Peptide Transmitters Released from Excitatory and Inhibitory Motor Neurons in Aplysia
}

\author{
Paul J. Church, Matthew D. Whim, and Philip E. Lloyd \\ Department of Pharmacological and Physiological Sciences and Committee on Neurobiology, University of Chicago, \\ Chicago, llinois 60637
}

The anterior portion of intrinsic buccal muscle 3 (13a) is innervated by two excitatory motor neurons, B3 and B38, and the newly identified inhibitory motor neuron, $B 47$. We show that B47 is cholinergic while B3 and B38 are not. B3 and B38 have previously been shown to express the neuropeptides FMRFamide and the small cardioactive peptides (SCPS) A and $B$, respectively. We present evidence here that B47 synthesizes the neuropeptide myomodulin A (Mma). When placed in culture, B3, B38, and B47 continued to synthesize their respective peptides. These peptides were released in a stimulation- and $\mathrm{Ca}^{2+}$-dependent manner, suggesting that they are transmitters in these neurons. By using B3-evoked excitatory junction potentials (EJPs) and muscle contractions as assays, we next examined the modulatory effects of superfusion of peptides and stimulation of motor neurons B38 and B47. Superfusing the muscle with low concentrations of the SCPs, FMRFamide, or Mma enhanced B3-evoked EJPs and contractions. Stimulation of B47 simultaneously with $\mathrm{B} 3$ reduced the amplitude of B3-evoked contractions. However, when either B47 or B38 was stimulated in extended bursts designed to release their peptide transmitters, subsequent B3-evoked EJPs and contractions were enhanced. We believe that this modulation is due at least in part to the release of peptides from the terminals of $B 38$ and $B 47$. The SCPs potently increase CAMP levels in 13a muscle fibers. Likewise, stimulation of B3B in extended bursts increased CAMP levels in the muscle. This provides independent evidence that the SCPs are released from B38 terminals in the muscle. Therefore, we have described a neuromuscular preparation amenable to the study of both excitatory and inhibitory motor neurons that utilize a variety of conventional and peptide transmitters. Our results suggest that these motor neurons can function in two states. When stimulated in single brief bursts, they primarily release conventional transmitters. When stimulated in a series of prolonged bursts, they release both conventional transmitters and peptide cotransmitters. These dual states are most pronounced in the case of B47, which, depending on the stimulation paradigm,

Received Aug. 3, 1992; revised Dec. 11, 1992; accepted Jan. 20, 1993.

We thank G. A. Phares for critical reading of the manuscript. This work was supported by NRSA 1-F31-MH10240-01 to P.J.C. and NS 23569 and BNS9121146 to P.E.L.

Correspondence should be addressed to Philip E. Lloyd, Department of Pharmacological and Physiological Sciences, University of Chicago, 947 East 58th Street, Chicago, IL 60637.

Copyright (C) 1993 Society for Neuroscience 0270-6474/93/132790-11\$05.00/0 can act selectively to inhibit or enhance the effects of a second motor neuron innervating the same muscle.

[Key words: neuropeptide, cholinergic, cAMP, synapse, cultured neurons]

One or more peptide transmitters often coexist with a conventional transmitter in individual neurons (Hokfelt et al., 1987). Knowledge of the properties governing release of conventional and peptide cotransmitters as well as their interactions on postsynaptic targets is crucial to our understanding of the physiological roles for each transmitter (Bartfai et al., 1988; Kupfermann, 1991). To study these issues we have used identified motor neurons in the buccal ganglia of Aplysia and their target muscles. These motor neurons generate the cyclic motor output that drives biting and swallowing movements of muscles of the buccal mass (Gardner, 1971; Kupfermann, 1974). There is mounting evidence that cotransmitters modulate several aspects of neuromuscular transmission (O'Shea and Schaffer, 1985; New and Mudge, 1986; Bishop et al., 1987; Cropper et al., 1988, 1990; Mulle et al., 1988; Calabrese, 1989; Whim and Lloyd, 1989, 1990). The Aplysia buccal system is an advantageous preparation to study cotransmission because identifiable neurons have discrete targets and express a variety of conventional and peptide cotransmitters.

Individual motor neurons in the buccal ganglia express one or more methionine-containing peptides along with their conventional transmitter (Lloyd et al., 1987b; Kupfermann et al., 1988; Church et al., 1991; Church and Lloyd, 1991a). These peptides include myomodulin A (Mma) (Cropper et al., 1987b), the two small cardioactive peptides $\left(\mathrm{SCP}_{\mathrm{A}}\right.$, Lloyd et al., 1987a; $\mathrm{SCP}_{\mathrm{B}}$, Morris et al., 1982), FMRFamide (Price and Greenberg, 1977), and buccalin A (Cropper et al., 1988). All of these peptides are transported by fast axonal transport to individual buccal muscles (Lloyd, 1988), where each is capable of modulating motor neuron-evoked contractions. Thus, it is very likely that these peptides function as modulatory transmitters in buccal muscle (Lloyd et al., 1984; Cropper et al., 1987a, 1990; Whim and Lloyd, 1990; Church and Lloyd, 1991b).

The most convincing evidence for release of peptide cotransmitters from terminals of identified motor neurons comes from studies of the cholinergic motor neuron $\mathrm{B} 15$, which synthesizes the SCPs and innervates intrinsic muscle 5 (I5; also termed ARC) (Cohen et al., 1978; Cropper et al., 1987a). The SCPs are located in dense-core vesicles in varicosities in this muscle (Cropper et al., 1987a). Two independent procedures have been used to demonstrate release of the SCPs from B15 terminals in 
I5 muscle (Whim and Lloyd, 1989). First, intracellular stimulation of B 15 produces a depletion of the SCPs from the stimulated muscle. Second, application of exogenous SCPs or stimulation of B 15 elevated cAMP levels in the stimulated muscle, indicating that depletion of the SCPs reflected their release. Release of the SCPs occurred only when B15 was stimulated at a relatively high frequency with a long burst duration. SCPs released from $\mathrm{B} 15$ terminals have been shown to modulate contractions evoked by stimulation of a second cholinergic motor neuron that innervates the I5 muscle (B16; Whim and Lloyd, 1990). Since B15 can produce cholinergically mediated contractions with stimulation parameters that do not cause measurable release of the SCPs, it has been suggested that B 15 can function in two states: as a predominantly cholinergic neuron, or as a combined cholinergic/peptidergic neuron. Release of the SCPs was observed when B 15 was stimulated in a pattern similar to that observed during feeding (Cropper et al., 1990). Thus, the release of peptide cotransmitters from B 15 has physiological consequences.

We recently completed a study designed to identify peptide transmitters expressed in identified motor neurons in the buccal ganglia of Aplysia (Church and Lloyd, 1991a). Using ${ }^{35} \mathrm{~S}-\mathrm{me}-$ thionine to label peptides synthesized in neurons, the expression patterns of five peptides were determined for approximately 20 identified motor neurons. These results have proven useful in designing physiological experiments to test the nature of interactions between motor neurons. The neuromuscular preparation that we chose for further study consists of intrinsic muscle 3 , anterior portion (the I3a muscle) and three motor neurons that innervate it: excitatory motor neurons B3 and B38, and the newly identified inhibitory motor neuron B47. Each of the three motor neurons that innervate I3a synthesizes a subset of the methionine-containing peptides. We used B3-evoked EJPs and muscle contractions to assay heterosynaptic modulation produced by excitatory motor neuron B38 and inhibitory motor neuron $\mathrm{B} 47$.

\section{Materials and Methods}

Animals. Aplysia californica (170-220 gm for biochemical and physiological experiments) were obtained from Marinus Inc. (Long Beach, CA), maintained in circulating artificial seawater (ASW) at $16^{\circ} \mathrm{C}$, and fed dried seaweed every $3 \mathrm{~d}$.

Identification of buccal motor neurons. Animals were immobilized with an injection of isotonic $\mathrm{MgCl}_{2}$. The dissection was carried out in a high- $\mathrm{Mg}^{2+}(110 \mathrm{~mm})$, low-Ca ${ }^{2+}(0.5 \mathrm{~mm}) \mathrm{ASW}$. The buccal mass/ buccal ganglia complex was removed and all nerves severed except ipsilateral buccal nerves 2 and 3 (nerve designations from Gardner, 1971; muscle nomenclature from Howells, 1942; see also Lloyd, 1988). The ganglia were desheathed and the preparation was superfused for 1$2 \mathrm{hr}$ with normal ASW (nASW). In all neuromuscular experiments, the ganglia were pinned in a small elevated, recessed chamber and selectively superfused with high- $\mathrm{Mg}^{2+}(165 \mathrm{~mm})$, high-Ca ${ }^{2+}(33 \mathrm{~mm})$ ASW to increase firing threshold and to inhibit spontaneous activity. The remainder of the bath containing the buccal muscles was superfused with nASW (sometimes containing peptides or other substances) unless otherwise indicated. Because of the geometry of the dish and the position of the ganglia relative to the superfusion inlets, the ganglia were exposed to $\sim 1000$-fold lower concentrations of the peptides or other substances applied to the muscle (as estimated by applying ${ }^{35} \mathrm{~S}$-methionine through the main bath and counting samples taken from the immediate vicinity of the ganglia). Neurons were typically impaled with two microelectrodes (4-8 M $\Omega$ ), one to inject current and one to monitor membrane potential. Motor neurons were identified by their position, size, nature of synaptic input, and muscle innervation patterns (see Church and Lloyd, 1991a).

Intracellular injection of ${ }^{3} \mathrm{H}$-choline and synthesis of labeled $A C \mathrm{c}$. Electrodes were tip-filled with a solution of $1 \mathrm{M} \mathrm{KCl}, 0.5 \%$ fast green, and ${ }^{3} \mathrm{H}$-choline $(\sim 70 \mathrm{Ci} / \mathrm{mmol}$; Amersham) concentrated to $0.2 \mathrm{mCi} /$ $\mu 1$. These electrodes gave acceptable voltage recording and were used to pressure inject the solution intracellularly into neuronal cell bodies. Ganglia wcre supcrfused with nASW containing $10 \mu \mathrm{M}$ cold choline to inhibit uptake of any leaked labeled choline. Identified neurons were pressure injected with the label solution and the change in cell color was monitored visually. After a l hr incubation period, neuronal cell bodies were dissected manually using freeze substitution (Ono and McCaman, 1980), extracted into $50 \mu \mathrm{l}$ of $85 \%$ ethanol, $15 \% 1 \mathrm{~m}$ acetic acid containing $300 \mathrm{nmol}$ each of cold choline and $\mathrm{ACh}$, maintained on dry ice, and then stored at $-20^{\circ} \mathrm{C}$. Samples were dried and run on reverse-phase HPIC (RP-HPIC). I abeled ACh could be separated completely from labeled choline and other labeled substances by RPHPLC on an Isco $5 \times 250 \mathrm{~mm} \mathrm{C8}(5 \mu \mathrm{m})$ column developed with a gradient from $8 \%$ to $20 \% \mathrm{CH}_{3} \mathrm{CN}$ in $7 \mathrm{~min}$, and then held at $20 \%$ for $2 \mathrm{~min}$ before re-equilibration. Both aqueous and $\mathrm{CH}_{3} \mathrm{CN}$ solutions contained $11 \mathrm{~mm}$ heptafluorobutyric acid (HFBA) and $1 \mathrm{~mm}$ triethylamine (TEA) as counterions. Fractions $(0.5 \mathrm{~min})$ were collected and counted after the addition of scintillation fluid. The label in the ACh peak was shown to be essentially all authentic ACh by three procedures: (1) incubation with electric eel acetylcholinesterase (Sigma V-S; $10 \mathrm{U} / \mathrm{ml}, 60$ min, $22^{\circ} \mathrm{C}$ ) completely hydrolyzed the labeled $\mathrm{ACh}$ peak to labeled choline; (2) incubation under basic conditions $(5 \mathrm{~mm} \mathrm{NaOH}, \mathrm{pH} 10$, $60 \mathrm{~min}, 22^{\circ} \mathrm{C}$ ) also completely hydrolyzed the labeled ACh peak to choline; (3) the labeled ACh peak continued to coelute precisely with cold ACh when run on a different mode of HPLC using 20 mM TEA acetate (pH 5, $0.1 \mathrm{~mm} \mathrm{Na-octyl} \mathrm{sulfate)} \mathrm{as} \mathrm{the} \mathrm{mobile} \mathrm{phase.}$

Peptide synthesis in identified neurons. Synthesis of methionine-containing peptides in the newly identified motor ncuron B47 was determined as previously described (Church and Lloyd, 1991a). Briefly, identified neurons were electrophoretically injected with a vital stain $(1 \%$ fast green) via an intracellular electrode. Synthesized peptides were labeled with $1 \mathrm{mCi} / \mathrm{ml}{ }^{35} \mathrm{~S}$-methionine (Amersham; stabilized with pyridine 3,4-dicarboxylic acid) for $20 \mathrm{hr}$, followed by a $4 \mathrm{hr}$ wash in $\mathrm{nASW}$ containing $1 \mathrm{~mm}$ cold methionine. Single cell bodies were dissected and transferred to microtubes containing $50 \mu \mathrm{l}$ of $0.02 \mathrm{M}$ trifluoroacetic acid (TFA) and $1 \mathrm{nmol}$ each of synthetic buccalin A (American Peptide Co.), FMRFamide (Bachem), myomodulin A, SCP Tubes were heated to $100^{\circ} \mathrm{C}$ for $10 \mathrm{~min}$ and the samples cooled, filtered, and analyzed by RP-HPLC on an Aquapore RP-300 C8 column (Pierce) using a $\mathrm{CH}_{3} \mathrm{CN}$ gradient and $0.01 \mathrm{~m} \mathrm{HFBA}$ as a counterion. This gradient effectively resolved the synthetic peptides. Fractions were collected, aliquoted, and liquid-scintillation counted. Some fractions were also subsequently analyzed using a second $\mathrm{CH}_{3} \mathrm{CN}$ gradient with $0.01 \mathrm{M}$ TFA as a counterion (Church and Lloyd, 1991a). Elution profiles of the synthetic peptides were determined from absorbance at $215 \mathrm{~nm}$.

Release of radiolabeled peptides from identified neurons in primary culture. Cells were cultured using previously described techniques (Schacher and Proshansky, 1983; Hall and Lloyd, 1991; Whim and Lloyd, 1992) with a few minor modifications. Neurons B3 and B38 were obtained from 70-100 gm animals. Due to their relatively small size, B47 neurons were obtained from $400 \mathrm{gm}$ animals. B3, B38, and B47 were identified using the physiological criteria described above. To aid later identification and to minimize damage to these neurons, surrounding neurons were injected with fast green. The isolated ganglia were incubated in a $1 \%$ protease solution (Sigma type IX) at $34^{\circ} \mathrm{C}$ for $\sim 2 \mathrm{hr}$. Neurons were then dissected and plated individually in $1.5 \mathrm{ml}$ wells (Nunc multidishes) in $500 \mu \mathrm{l}$ culture medium (50\% sterile nASW, $50 \%$ Aplysia hemolymph) containing penicillin-streptomycin-fungizone (GIBCO) at a concentration of $1 \%$. Following $36 \mathrm{hr}$ in culture, newly synthesized peptides were labeled by the addition of ${ }^{35} \mathrm{~S}$-methionine $(0.5$ $\mathrm{mCi} / \mathrm{ml}$ ) for $24 \mathrm{hr}$, then washed with a high- $\mathrm{Mg}^{2+}$, low- $\mathrm{Ca}^{2+} \mathrm{ASW}$ for 4-8 hr.

Cultured neurons were impaled with two electrodes, one to inject current, the other to monitor membrane potential. Cells were typically tonically active $(2-7 \mathrm{~Hz})$ and were hyperpolarized to just below threshold throughout the experiment except during the stimulation periods. The culture well was perfused at a rate of $0.5 \mathrm{ml} / \mathrm{min}(\sim 1$ bath vol/ $\mathrm{min}$ ) for $30 \mathrm{~min}$ prior to the first collection period. The perfusate contained bovine serum albumin $(14 \mu \mathrm{g} / \mathrm{ml})$ to protect the released peptides. Experiments consisted of three collection periods, each lasting $15 \mathrm{~min}$. In the first collection period the well was perfused with high- $\mathrm{Mg}^{2+}$, low$\mathrm{Ca}^{2+}$ ASW and the cell was stimulated at $15 \mathrm{~Hz}$ for $4 \mathrm{sec}$ with $3 \mathrm{sec}$ interburst intervals for $5 \mathrm{~min}$, and then held hyperpolarized for $10 \mathrm{~min}$. The perfusate was then changed to $\mathrm{nASW}$. After $15 \mathrm{~min}$ for equilibra- 


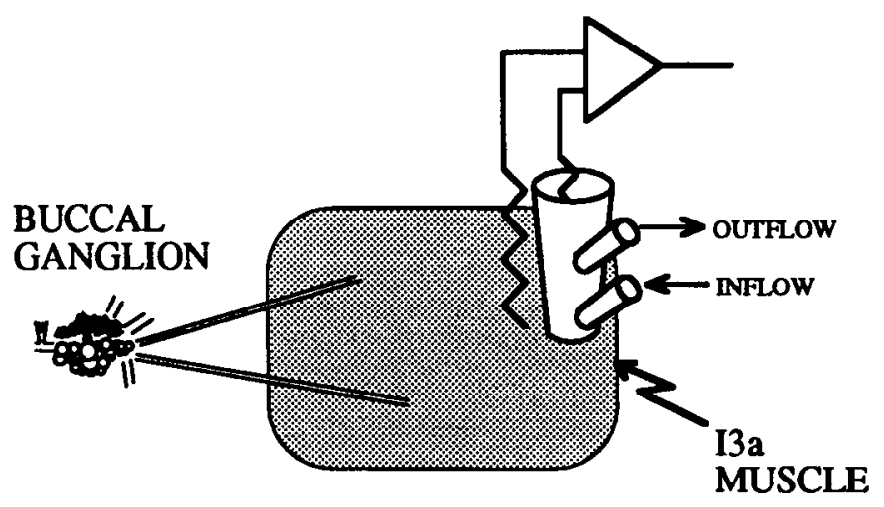

Figure 1. Diagram of the perfusion electrode. The inside of the electrode was perfused with nASW while the remainder of the muscle was superfused with high-Mg ${ }^{2+}$, low-Ca ${ }^{2+}$ ASW to block synaptic transmission and muscle contractions. EJPs and IJPs were measured by extracellular electrodes placed inside and just outside the wall of the electrode.

tion, two further collection periods were taken. In the first, the neuron was held hyperpolarized; in the second, the neuron was again stimulated at $15 \mathrm{~Hz}$ for $4 \mathrm{sec}$ with $3 \mathrm{sec}$ interburst intervals for $5 \mathrm{~min}$ followed by a $10 \mathrm{~min}$ hyperpolarization. Perfusate from each period was collected on ice, and acidified with TFA (final concentration, $10 \mathrm{~mm}$ ) spiked with $2 \mathrm{nmol}$ each of unlabeled $\mathrm{SCP}_{\mathrm{A}}, \mathrm{SCP}_{\mathrm{B}}$, buccalin, FMRFamide, and myomodulin $\mathrm{A}$, and $1 \mathrm{mM}$ mercaptoethanol (to reduce oxidation of methionine residues). After collection, the samples were immediately passed through a C18 Sep-pak (Waters). Retained material was eluted with $2 \mathrm{ml}$ of $90 \% \mathrm{CH}_{3} \mathrm{CN}$ containing $10 \mathrm{~mm}$ TFA, lyophilized, and run on RP-HPLC using a $\mathrm{CH}_{3} \mathrm{CN}$ gradient with HFBA as a counterion as described above (Church and Lloyd, 199 la). Fractions were collected, and then counted using a liquid scintillation counter.

Measurement of 13 a muscle contractions. Neurons were impaled with two electrodes. Individual spikes were driven by brief $(10 \mathrm{msec}) \mathrm{de}-$ polarizing current pulses. Reproducible submaximal I3a muscle contractions were evoked by stimulating B3 at $16 \mathrm{~Hz}$ for $1.6 \mathrm{sec}$ with an interburst interval of 50 or $100 \mathrm{sec}$. Contraction amplitudes were monitored with an isotonic transducer (Harvard Apparatus). All experiments were performed at room temperature $\left(\sim 22^{\circ} \mathrm{C}\right)$ unless otherwise indicated. Peptides to be tested for their actions on B3-evoked contractions were dissolved in nASW and applied via the superfusion. Note that the ganglion was separately superfused with high- $\mathrm{Mg}^{2+}$, high-Ca ${ }^{2+} \mathrm{ASW}$ and was not exposed to significant concentrations of these substances (see above).

Measurement of I 3 a EJPS and IJPs. Neurons were impaled and stimulated as described above. Excitatory junction potentials (EJPs) and inhibitory junction potentials (IJPs) were recorded via a perfusion electrode. This electrode consisted of a small chamber $(250 \mu \mathrm{l})$ with a small aperture (diameter $-1.5 \mathrm{~mm}$ ) that was positioned to press down firmly on a portion of the I3a muscle (Fig. 1). The inside of this chamber was superfused rapidly with $\mathrm{nASW}(6 \mathrm{vol} / \mathrm{min})$. The remainder of the muscle outside of the recording chamber was superfused with high- $\mathrm{Mg}^{2+}$, low$\mathrm{Ca}^{2+}$ ASW to block synaptic transmission and muscle contractions. This procedure confined the contractions to the small area of the muscle covered by the recording chamber and thus markedly reduced movement artifacts in the recordings. Muscle contractions do not begin until after the tenth EJP, so at least the first 10 EJPs of a burst (at $15 \mathrm{~Hz}$ ) are recorded in the absence of any movement. EJPs and IJPs were recorded by extracellular electrodes placed inside and just outside the wall of the perfusion apparatus. Signals were amplified using a Grass P15D AC amplifier. Peptides to be tested for their actions on evoked EJPs were applied with the nASW through the perfusion electrode.

Measurement of CAMP. cAMP levels in I3a muscle were measured as previously described for the 15 muscle (Whim and Lloyd, 1989). After intracellular stimulation of B38 or B3 on one side of the preparation, both 13 a muscles were frozen with an electronic component freezer spray (Miller-Stephenson Chemical Co., Danbury, CT), and then homogenized in $98 \%$ ethanol and $2 \% 2 \mathrm{~N} \mathrm{HCl}$ at $-30^{\circ} \mathrm{C}$ and centrifuged at $10,000 \times g$. The supernatants were used for cAMP determinations using a commercial cAMP-binding protein assay (Amersham), while the pellets were used for protein determinations (Pierce Chemicals). These experiments were performed at $16^{\circ} \mathrm{C}$ because previous experiments carried out using a different buccal neuromuscular preparation indicated that peptide release was increased by lowering the temperature (Whim and Lloyd, 1990). Preliminary experiments in the I3a neuromuscular system suggest that it also shows a similar dependence on temperature.

\section{Results}

\section{Identification of neurons}

Motor neurons B3 and B38 have been previously identified (Gardner, 1971; Lotshaw and Lloyd, 1990). The newly identified buccal motor neuron B47 was usually less than $40 \mu \mathrm{m}$ in diameter ( $\sim 200 \mathrm{gm}$ animals) and was located on the caudal surface of each ganglion, medial to the identified neuron B2. Based on Lucifer yellow fills and suction electrode nerve recordings, B47 has a single major neurite that projects out buccal nerve 2 . In nASW, B47 is often spontaneously active $(1-5 \mathrm{~Hz})$. When spontaneous activity was silenced by selectively superfusing the ganglion with high- $\mathrm{Mg}^{2+}$, high-Ca ${ }^{2+} \mathrm{ASW}$, stimulation of $\mathrm{B} 47$ evoked one-for-one IJPs in the I3a muscle with a constant latency (Fig. 2). In addition, when B47 was stimulated simultaneously with an excitatory I3a motor neuron, the associated muscle contraction was reduced in amplitude compared to that evoked by the excitatory motor neuron alone (see Fig. 12). Thus, B47 was determined to be an inhibitory motor neuron. Most I3a muscle fibers are innervated by B3, B38, and B47, while some fibers are innervated by a subset of the three motor neurons. No direct synaptic connections between these three motor neurons were observed.

\section{B47 is cholinergic}

It has been shown repeatedly that synthesis of $\mathrm{ACh}$ from injected labeled choline is a powerful criterion in determining if an Aplysia neuron is cholinergic (Eisenstadt et al., 1973; Cohen et al., 1978). Individual neurons were identified, pressure injected with ${ }^{3} \mathrm{H}$-choline, dissected, and run on RP-HPLC. Examples of labeling patterns of B3, B38, and B47 are shown in Figure 3. B47, but not B3 or B38, synthesized a significant amount of labeled $\mathrm{ACh}$. A major labeled product in all neurons studied is an unidentified substance(s). Using the same procedures, the profile of labeled material in B47 is very similar to that observed in cholinergic excitatory motor neurons B1 5 and B16 (P. E. Lloyd and P. J. Church, unpublished observations). B3 and B38 were determined to be noncholinergic by the criteria that they contained essentially no CAT activity and that their evoked contractions were not blocked by $d$-tubocurarine $\left(10^{-4} \mathbf{M}\right)$ or hcxamethonium $\left(10^{-4} \mathbf{M}\right)$ and were not desensitized by $\mathrm{ACh}\left(10^{-3}\right.$ M) (see Cohen et al., 1978). B47 is cholinergic by the criteria that it contains significant CAT activity and that its inhibitory effects on B3-evoked contractions are blocked by $d$-tubocurarine and desensitized by $\mathrm{ACh}$. The magnitude of the inhibition of B3-evoked contractions produced by B47 stimulation was reduced $87 \pm 4 \%$ (mean $\pm \mathrm{SD}, n=4$ ) by $10^{-4}$ м $d$-tubocurarine and $93 \pm 6 \%(n=4)$ by $10^{-3} \mathrm{M} \mathrm{ACh}$. In these experiments B47 was stimulated at $15 \mathrm{~Hz}$ for $1.6 \mathrm{sec}$ simultaneously with $16 \mathrm{~Hz}$ B3 bursts. Although somewhat nonspecific in Aplysia, $d$-tubocurarine has been used previously because it is one of the few substances found to be effective at inhibiting cholinergic IPSPs between central neurons (Ascher and Kehoe, 1975; Gardner and Kandel, 1977) or IJPs in anterior aorta muscle (Sawada et al., 1981). 


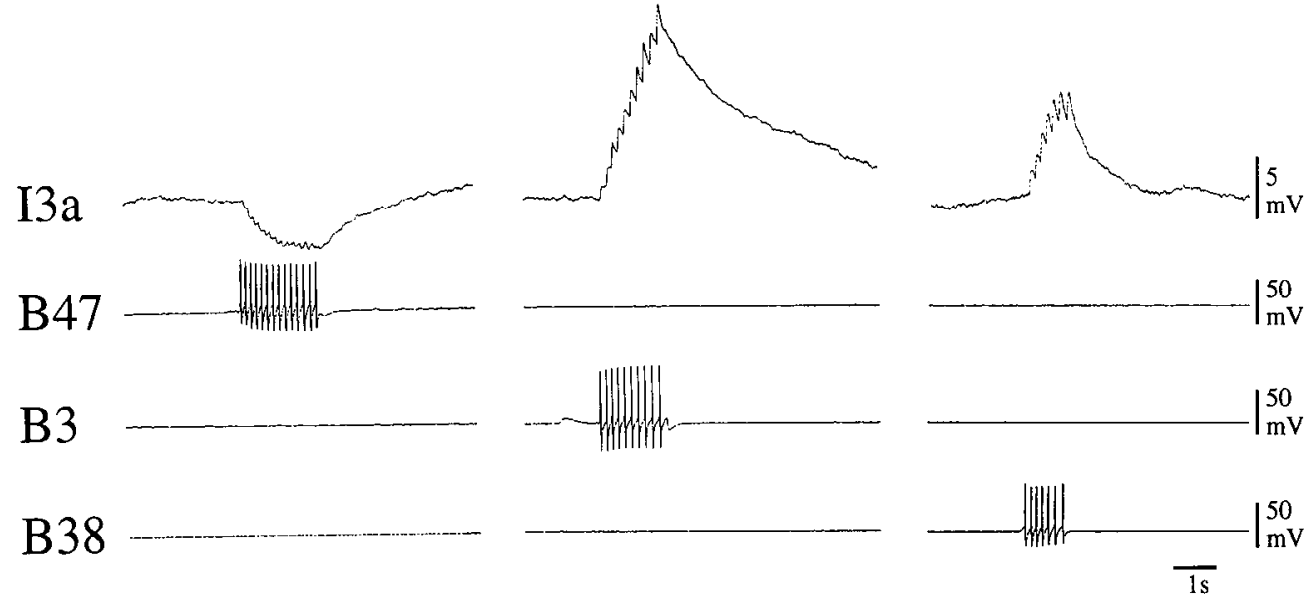

Figure 2. IJPs and EJPs recorded in I3a muscle. In all three panels, the top trace is an intracellular recording from the same I3a muscle fiber and the bottom three traces are simultaneous intracellular recordings from motor neurons $\mathrm{B} 47, \mathrm{~B} 3$, and $\mathrm{B} 38$. Action potentials in the neurons evoked onefor-one IJPs in the muscle fiber in the case of B47, and EJPs in the cases of B3 and B38. Neurons were recorded and stimulated through single electrodes and traces were AC coupled.

\section{B47 synthesizes Mma}

Synthesis of methionine-containing neuropeptides by B47 was determined. B47 expressed Mma and a second, smaller peak (Fig. 4). The smaller peak has been observed in all Mma-synthesizing neurons analyzed thus far in a ratio of approximately 5:1 (Fig. 4). This second peak is likely to include the recently sequenced myomodulin B (Mmb; Villim et al., 1989; Church and Lloyd, 1991a). Aliquots from the labeled peaks that coeluted with synthetic Mma were run on RP-HPLC with TFA as a counterion to confirm peptide identifications. The labeled peak continued to coelute with synthetic Mma. The percentage of recovered counts in B47 that coeluted with synthetic Mma was $9.4 \pm 5.5$ (mean $\pm \mathrm{SD}, n=4$ ). B3 and B38 were previously shown to synthesize FMRFamide and the SCPs, respectively (Lotshaw and Lloyd, 1990; Church and Lloyd, 1991a). We reported rates of expression of $3.4 \pm 1.3 \%$ for FMRFamide in B3 and $11.1 \pm 7.4 \%$ for the SCPs in B38 (Church and Lloyd, 1991a). Thus, inhibitory motor neuron B47 synthesizes a peptide cotransmitter at levels comparable to those found in the excitatory motor neurons.

\section{Release of radiolabeled peptides from neurons in primary culture}

One important test for the classification of a chemical as a transmitter is that it be released in a stimulation-dependent manner. To study this question, we examined whether the neuropeptides synthesized by neurons in vivo could be released from identified cells in culture. Neurons B3, B38, and B47 were individually cultured and incubated with ${ }^{35} S$-methionine to label newly synthesized peptides. Cells were impaled with two microelectrodes and the culture wells were perfused. Perfusate was collected during three periods, each $15 \mathrm{~min}$ in duration. In the first collection period the culture well was perfused with high$\mathrm{Mg}^{2+}$, low-Ca ${ }^{2+} \mathrm{ASW}$ and the neuron was stimulated at $15 \mathrm{~Hz}$ for $4 \mathrm{sec}$ with $3 \mathrm{sec}$ interburst intervals for $5 \mathrm{~min}$. In the second collection period, the culture well was perfused with nASW and the neuron was held hyperpolarized. In the third collection period the culture well was perfused with nASW and the neuron was stimulated as in the first collection period. Perfusate from each collection period was run on RP-HPLC and the fractions were counted. When neurons were stimulated in nASW, there was a marked increase in the number of counts that coeluted with the synthetic peptide expressed by each neuron in situ (Fig. 5). Thus, each motor neuron released a neuropeptide in a $\mathrm{Ca}^{2+}$ and stimulation-dependent manner.
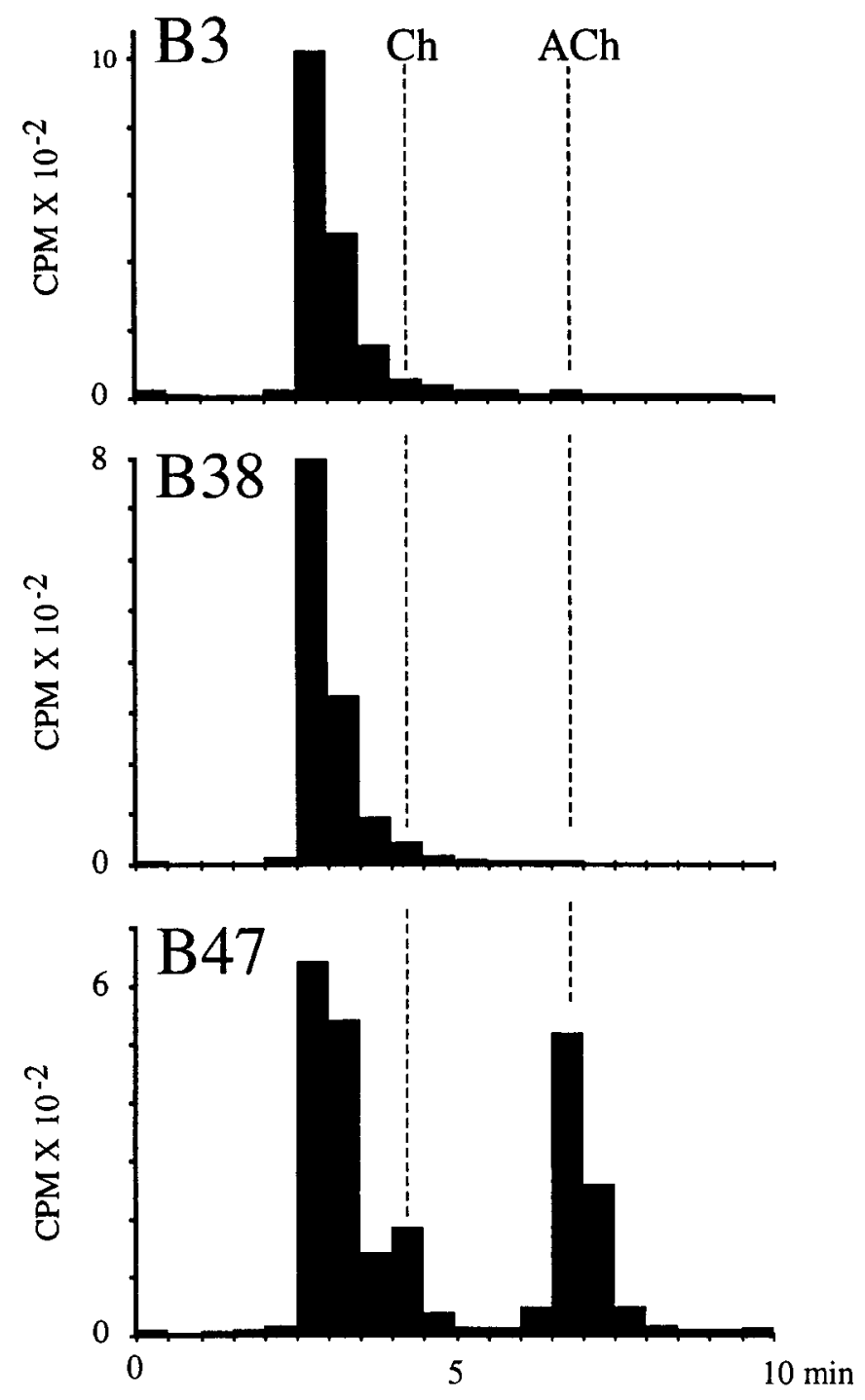

Figure 3. RP-HPLC profiles of extracts from single identified neuronal somata injected with ${ }^{3} \mathrm{H}$-choline. Neurons were dissected and extracted $\sim 1 \mathrm{hr}$ after injection. Very low levels of labeled ACh were synthesized by $\mathrm{B} 3(0.6 \pm 0.8 \%$ of total recovered counts, $\pm \mathrm{SD}, n=9)$ and $\mathrm{B} 38(0.5$ $\pm 0.4 \%, n=9)$. B47 synthesized high levels of labeled ACh $(29.6 \pm$ $11.4 \%, n=4)$. Dashed lines indicate retention times of cold choline and ACh added to the cell extract and monitored by absorbance at $206 \mathrm{~nm}$. The large peak with retention time of $\sim 3 \mathrm{~min}$ has not been identified. 


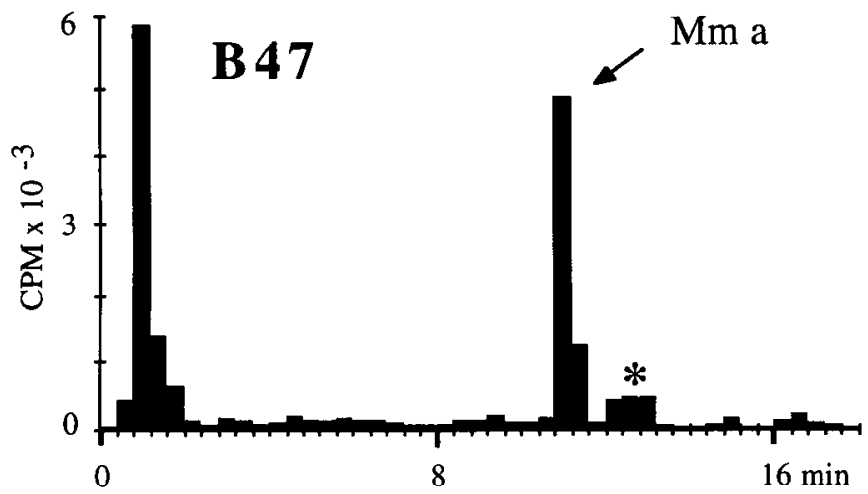

Figure 4. Example of RP-HPLC of an extract from a single B47 neuron dissected from a ganglion labeled with ${ }^{35} \mathrm{~S}$-methioninc. Cell extracts were run with HFBA as a counterion. Retention time of synthetic Mma was identical to that of the major labeled peptide peak (indicated by the arrow). Peptide identity was confirmed by running aliquots from the peaks on RP-HPLC with TFA as a counterion. The smaller peak indicated by the asterisk probably includes the recently sequenced $\mathrm{Mmb}$ (see Villim et al., 1989). Unincorporated ${ }^{35} S$-methionine is the predominant component of the large peak with brief retention time $(0-3 \mathrm{~min})$.

In addition to counts coeluting with synthetic FMRFamide, stimulation of B3 also resulted in the release of a second peak of radioactivity that was $\mathrm{Ca}^{2+}$ and stimulation dependent $(9 \pm$ $6 \%$ in collection period $1,8 \pm 3 \%$ in period $2,82 \pm 8 \%$ in period 3; percentage of total counts that comprised this unidentified peak). Total counts in these fractions were $200 \pm 75$ cpm (mean $\pm \mathrm{SD}, n=3$ ). This peak does not coelute with oxidized FMRFamide and its identity is currently under investigation.

\section{Modulation of B3-evoked muscle contractions and EJPs by exogenous neuropeptides}

As described above, I3a muscle fibers are innervated by motor neurons that synthesize the SCPs (B38), FMRFamide (B3), or myomodulins (B47). Superfusion of each of these peptides over the muscle was found to modulate B3-evoked EJPs and muscle contractions. The SCPs and FMRFamide enhanced the amplitude of B3-evoked contractions at $10^{-8} \mathrm{M}$ and $10^{-6} \mathrm{M}$ concentrations (Figs. 6, 9). Mma enhanced muscle contractions at $10^{-8}$ $\mathrm{M}$ and reduced contraction amplitude at $10^{-6} \mathrm{M}$ (Figs. 6, 9). B3evoked contractions were often enhanced during the washout of $10^{-6} \mathrm{M}$ Mma. The peptides had similar effects on B38-evoked contractions. The SCPs, FMRFamide, and Mma enhanced B3evoked EJP amplitudes at $10^{-8} \mathrm{M}$ and $10^{-6} \mathrm{M}$ concentrations (Figs. 7-9). Superfusion of the muscle with $10^{-6} \mathrm{M}$ Mma increased B3-evoked EJPs but decreased B3-evoked contractions, suggesting that this concentration of Mma must also produce a secondary inhibition at some level in excitation-contraction coupling (Brezina et al., 1992).

\section{Modulation of contraction and EJP amplitudes by stimulation of excitatory motor neurons}

We examined the effects of stimulating excitatory motor neuron B38 on B3-evoked muscle contractions and EJPs. B3 was stimulated at $100 \mathrm{sec}$ intervals to evoke reproducible submaximal muscle contractions. As expected, stimulating B38 and B3 simultaneously resulted in larger contractions than those produced by either motor neuron alone (not shown). We then stimulated B38 in extended bursts during a B3 interburst interval. Similar stimulation paradigms have been shown to evoke pep-
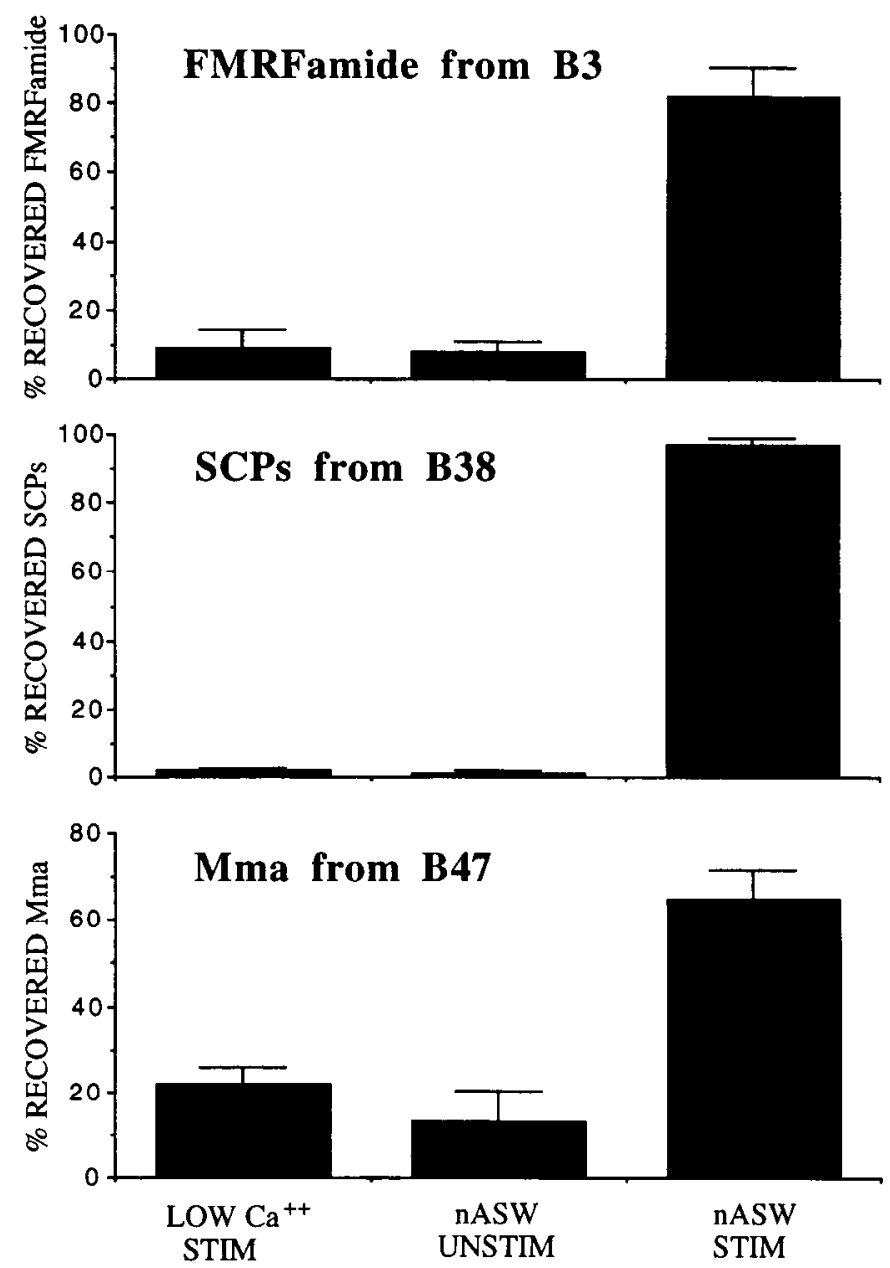

Figure 5. Release of ${ }^{35} \mathrm{~S}$-methionine-labeled peptides from cultured identified neurons. Histograms represent the percentage of total counts that coeluted with the respective synthetic peptide from three collection periods. B3 released FMRFamide (total counts $=73 \pm 14 \mathrm{cpm}$ ), B38 released the SCPs $(1201+1154 \mathrm{cpm})$, and $\mathrm{B} 47$ released Mma $(30 \pm$ $3 \mathrm{cpm}$ ) in a stimulation- and $\mathrm{Ca}^{2+}$-dependent manner. Values expressed as mean $\pm \mathrm{SD}, n \geq 3$. B3 released a second unidentified peak of radiolabel in a stimulation- and $\mathrm{Ca}^{2+}$-dependent manner (see Results). Insufficient counts were collected from the B47 perfusate to determine whether Mmb was also released from this cell.

tide cotransmitter release from other motor neurons in Aplysia (Whim and Lloyd, 1989; Cropper et al., 1990). Subsequent B3evoked contractions and EJPs were enhanced in amplitude (Figs. $10,11)$. The magnitude of the modulation of the B3-evoked contractions increased as the B38 stimulation frequency was increased (Fig. 10). This effect was reversible, with the B3-evoked contractions returning to control values within about $30 \mathrm{~min}$.

The reciprocal experiment with the two excitatory motor neurons was also carried out. B38 was stimulated with an interburst interval of $100 \mathrm{sec}$, which produced reproducible submaximal I3a muscle contractions. When B3 was stimulated in extended bursts during a B38 interburst interval, subsequent B38-evoked contractions were enhanced in amplitude $(32 \pm 18 \%$ increase, $\pm \mathrm{SD}, n=4$; B3 stimulated at $15 \mathrm{~Hz}$ for $4 \mathrm{sec}$ every $10 \mathrm{sec}$ for $60 \mathrm{sec}$ ). Likewise, when B3 was stimulated in extended bursts, subsequent B38-evoked EJPs were enhanced in amplitude (16 $\pm 6 \%$ increase, $n=3$; B3 stimulated as above, for $80 \mathrm{sec}$ ). B38evoked contractions and EJPs also returned to control amplitudes within about $30 \mathrm{~min}$. 

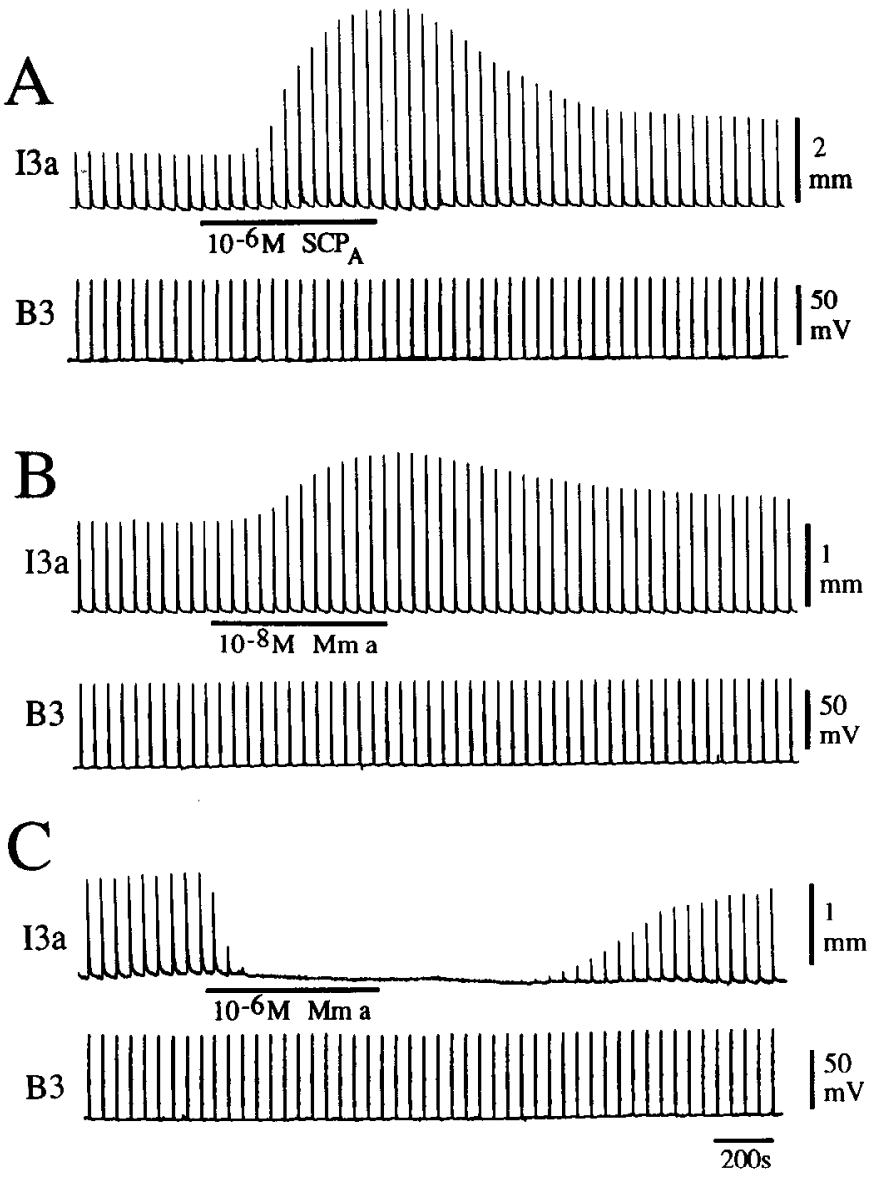

Figure 6. Modulation of B3-evoked 13a muscle contractions by exogenous peptides. In each pair of traces, the top trace is a recording of contractions of the I3a muscle, while the bottom trace is an intracellular recording from B3. Contractions were evoked by stimulation of B3 at $16 \mathrm{~Hz}$ for $1.6 \mathrm{sec}$ with $50 \mathrm{sec}$ interburst intcrvals. $A$, Muscle contractions produced by bursts of action potentials in $\mathrm{B} 3$ were reversibly increased by superfusion with $10^{-6} \mathrm{M} \mathrm{SCP}_{\mathrm{A}}$ over the muscle. $B$, Muscle contractions were reversibly increased by superfusion with $10^{-8} \mathrm{M} \mathrm{Mma.} C$, Muscle contractions were reversibly inhibited by superfusion with $10^{-6}$ $\mathrm{M} \mathrm{Mma} . B$ and $C$ are from the same preparation. In all experiments the ganglia were selectively superfused with high- $\mathrm{Mg}^{2+}$, high- $\mathrm{Ca}^{2+}$ ASW (see Materials and Methods) to eliminate spontaneous activity and prevent exposure to exogenously applied peptides.

\section{Modulation of contraction and EJP amplitudes by stimulation of inhibitory motor neuron $B 47$}

When B47 was stimulatcd simultaneously with B3, the evoked contraction was reduced in amplitude (Fig. 12). As the B47 stimulation frequency was increased the magnitude of this inhibition increased (Fig. 12). However, when B47 was stimulated in extended bursts during the B3 interburst interval, subsequent B3-evoked contractions and EJPs were enhanced in amplitude (Figs. 12, 13). The enhancement of the B3-evoked contractions also increased with B47 stimulation frequency (Fig. 12). The amplitude of B3-evoked contractions and EJPs returned to control values within about $30 \mathrm{~min}$.

\section{Motor neuron modulation of muscle cAMP levels}

Potentiation of I 3 a contractions by the SCPs has been attributed to two broad mechanisms (Lotshaw and Lloyd, 1990). One is the increase in EJP amplitude described above. The other is a cAMP-mediated modulation of excitation-contraction coupling
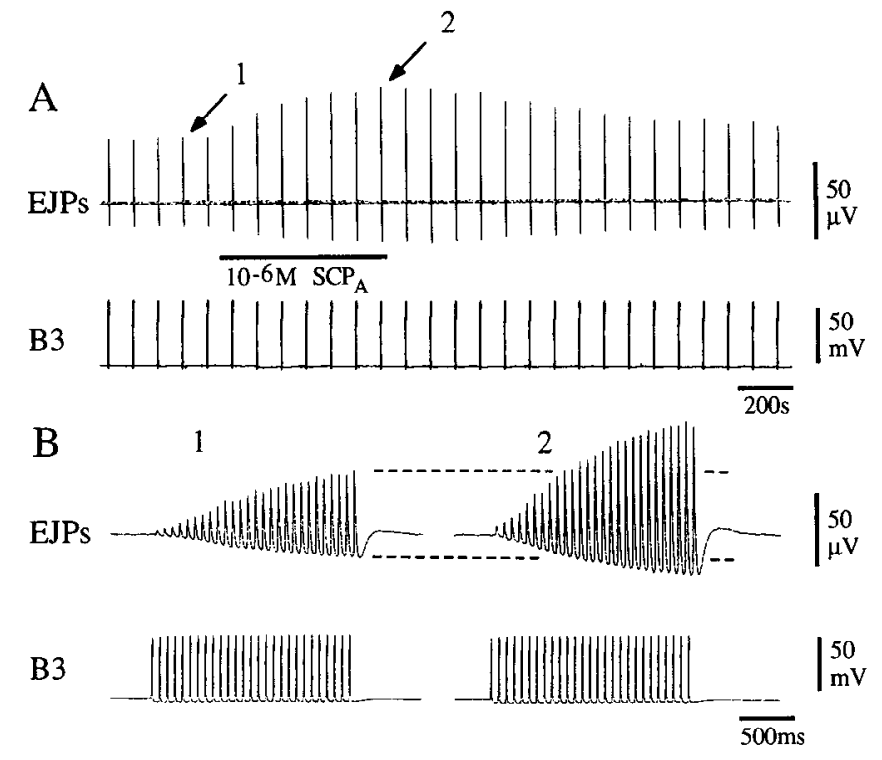

Figure 7. Modulation of B3-evoked EJPs by exogenous $\mathrm{SCP}_{\mathrm{A}}$. In each pair of traces, the top trace is an extracellular recording of the I3a muscle, and the bottom trace is an intracellular recording of motor neuron B3. EJPs were evoked by stimulating B3 at $16 \mathrm{~Hz}$ for $1.6 \mathrm{sec}$ with $100 \mathrm{sec}$ interburst intervals. $A, \mathrm{SCP}_{\mathrm{A}}$ at $10^{-6} \mathrm{M}$ produced a reversible increase in the amplitude of B3-evoked EJPs. $B$, Examination of B3-evoked EJPs with an expanded time scale before (1) and during (2) superfusion with $10^{-6} \mathrm{M} \mathrm{SCP}$.

in I3a muscle fibers similar to that observed in another buccal muscle (Weiss et al., 1978, 1979). Application of exogenous SCPs to I3a muscle produces large increases in cAMP levels in the muscle fibers (Lotshaw and Lloyd, 1990). We reasoned that if stimulation of B38 did release SCPs from terminals in the I3a muscle, this release should lead to an increase in cAMP levels

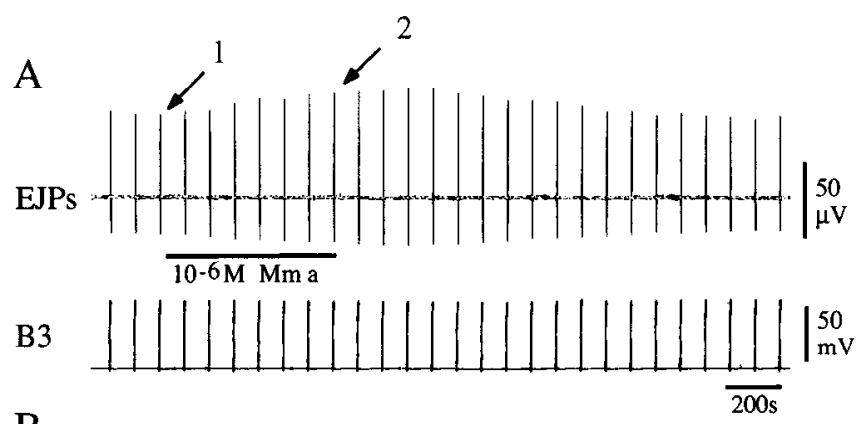

B

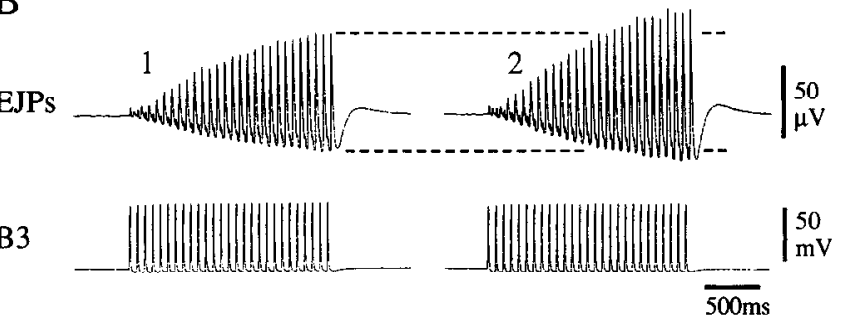

Figure 8. Modulation of B3-evoked EJPs by exogenous Mma. In each pair of traces, the top trace is an extracellular recording of the I3a muscle, and the bottom trace is an intracellular recording of motor neuron B3. EJPs were evoked by stimulating B3 at $16 \mathrm{~Hz}$ for $1.6 \mathrm{sec}$ with $100 \mathrm{sec}$ interburst intervals. $A, \mathrm{Mma}$ at $10^{-6} \mathrm{M}$ produced a reversible increase in the amplitude of B3-evoked EJPs. $B$, Examination of B3-evoked EJPs with an expanded time scale before (1) and during (2) superfusion with $10^{-6}$ M Mma. 

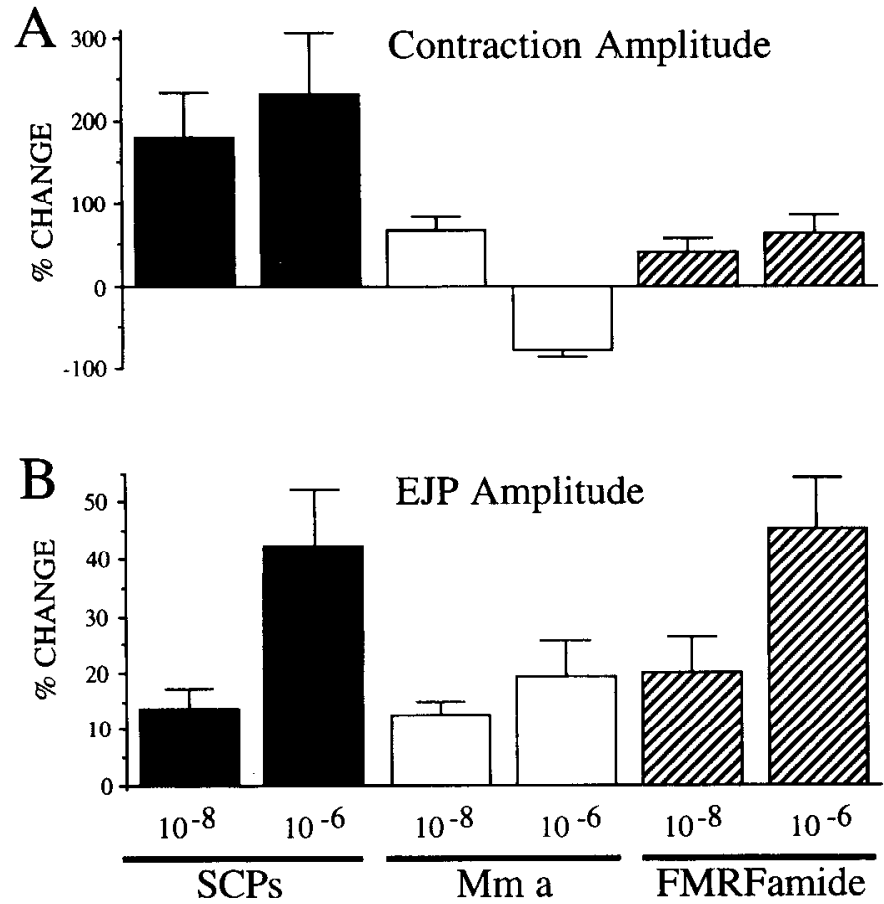

Figure 9. Summary of the modulation of B3-evoked I3a contractions and EJPs produced by superfusion with exogenous peptides at two concentrations. $A$, Effects of superfusion of peptides on contractions. $B$ Effects of superfusion of peptides on B3-evoked EJP amplitude. Concentrations are in moles/liter. Values are mean $\pm \operatorname{SEM}(n \geq 4)$.

in the muscle. Similar experiments have been carried out with B15 and muscle 15 (Whim and Lloyd, 1989; Cropper et al., 1990). cAMP normalized to protein in the experimental muscle was compared to that in the paired control muscle. When the B38 that innervated the experimental muscle was hyperpolarized for $10 \mathrm{~min}$, the ratio of cAMP levels in the experimental muscle compared to the contralateral control muscle was $1.2 \pm$ 0.2 (for all cAMP experiments, valucs arc cxpresscd as mean $\pm \mathrm{SEM}, n=4)$. When $\mathrm{B} 38$ was stimulated at $10 \mathrm{~Hz}$, this cAMP ratio was significantly higher (Fig. $14 ; t=6.02, p<0.001$, Student's $t$ test) than when B38 was held hyperpolarized. In contrast, when B3 was stimulated at identical or even higher frequencies $(10$ or $12.5 \mathrm{~Hz}$ ), the cAMP ratio in the 13 a muscle $(10 \mathrm{~Hz}, 1.6 \pm 0.2 ; 12.5 \mathrm{~Hz}, 1.4 \pm 0.1)$ was not significantly different $(10 \mathrm{~Hz}, t=1.5 ; 12.5 \mathrm{~Hz}, t=1.11$; for both, $0.8<p)$ from that observed when B38 was held hyperpolarized. At frequencies higher than $10 \mathrm{~Hz}, \mathrm{~B} 38$ rarely evoked EJPs that followed one for one with somatic spikes throughout the $10 \mathrm{~min}$ stimulation period. In one experiment in which B38 did reliably evoke EJPs at $12.5 \mathrm{~Hz}$, the cAMP level in the target I3a muscle was elevated 9.8 -fold over the level in the control muscle. Thus, B38 but not B3 evokes a stimulation-dependent increase in cAMP levels in the I3a muscle.

\section{Discussion}

In the present study, we investigated the interactions of conventional and peptide transmitters at a neuromuscular preparation in Aplysia. The preparation consists of two noncholinergic excitatory motor neurons (B3 and B38) and the newly identified cholinergic inhibitory motor neuron (B47) and their target muscle. Although inhibitory motor neurons have been previously found in Aplysia (Carew et al., 1974; Banks, 1975; Nagahama
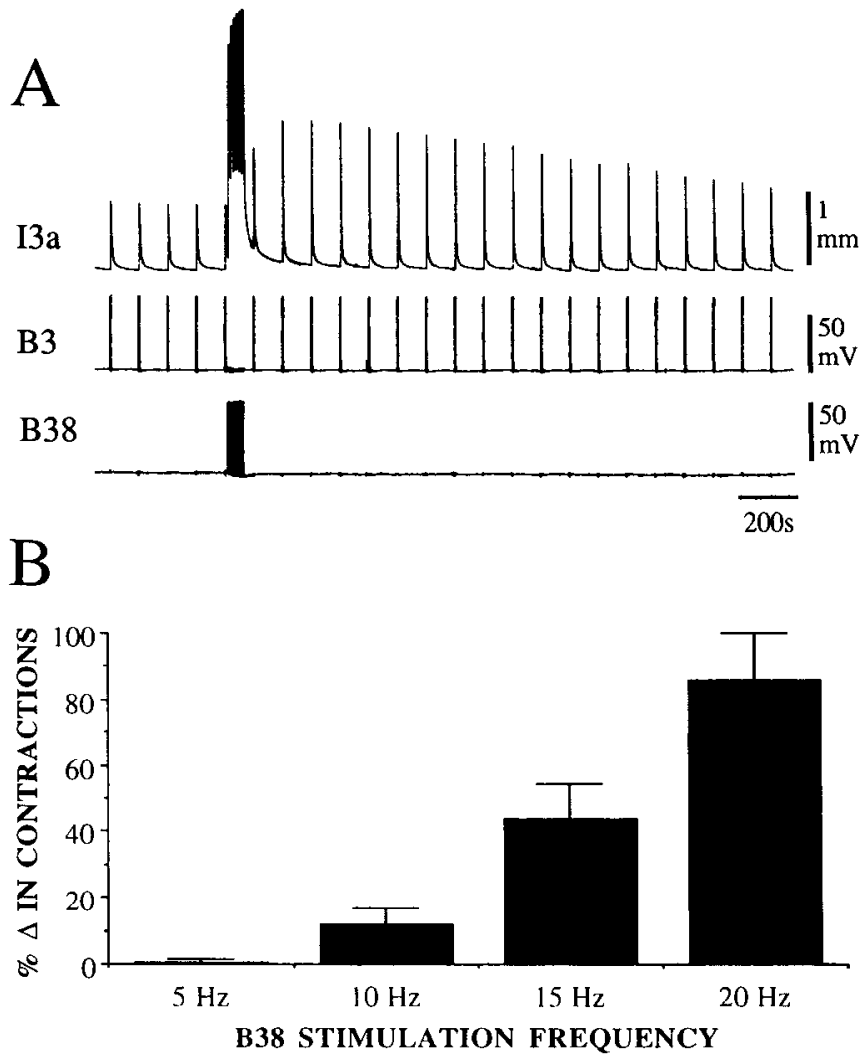

Figure 10. Modulation of B3-evoked I3a muscle contractions by stimulation of B38. $A$, The top trace monitors contractions of the I3a muscle, the middle trace is an intracellular recording from $\mathrm{B} 3$, and the bottom trace is an intracellular recording from B38. Stimulation of B3 at 16 $\mathrm{Hz}$ for $1.6 \mathrm{sec}$ with $100 \mathrm{sec}$ interburst intervals elicited reproducible contractions. B38 was stimulated $(20 \mathrm{~Hz}$ for $4 \mathrm{sec}$ with a $6 \mathrm{sec}$ interburst interval for $60 \mathrm{sec}$ ) $10 \mathrm{sec}$ into a B3 interburst interval. The subsequent B3-evoked muscle contractions were increased in amplitude. $B$, Summary of the effects of stimulating B38 on B3-evoked muscle contractions. B38 was stimulated at the indicated frequencies in $4 \mathrm{sec}$ bursts with $6 \mathrm{sec}$ interburst intervals for $60 \mathrm{sec}$. Values are mean \pm SEM ( $n$ $=4)$.

and Takata, 1990), they appear to be considerably less common than excitatory motor neurons. The majority of identified buccal motor neurons are cholinergic and excitatory (Lloyd and Church, unpublished observations). However, in the muscle fibers we have studied in which the cholinergic motor neurons evoke either an inhibitory or a mixed response, the purely excitatory motor neurons to those fibers are noncholinergic. The identity of the excitatory transmitter used by these neurons is currently unknown.

B3 and B38 were previously shown to express FMRFamide (Church and Lloyd, 1991a) and the SCPs (Lotshaw and Lloyd, 1990), respectively. The newly identified inhibitory motor neuron B47 expresses Mma. We demonstrate that B3, B38, and B47 neurons, when grown in primary cell culture, release FMRFamide, the SCPs, and Mma, respectively, in a $\mathrm{Ca}^{2+}$ - and stimulation-dependent manner. Stimulation of B3 also released a second peak of radiolabel. While this peak does not coelute with the oxidized form of FMRFamide, it is still possible that it is a chemically modified form of FMRFamide. The nature of the unidentified substance is currently under investigation. The expression and release of methionine-labeled peptides may also reflect the presence of other peptides processed from the same 

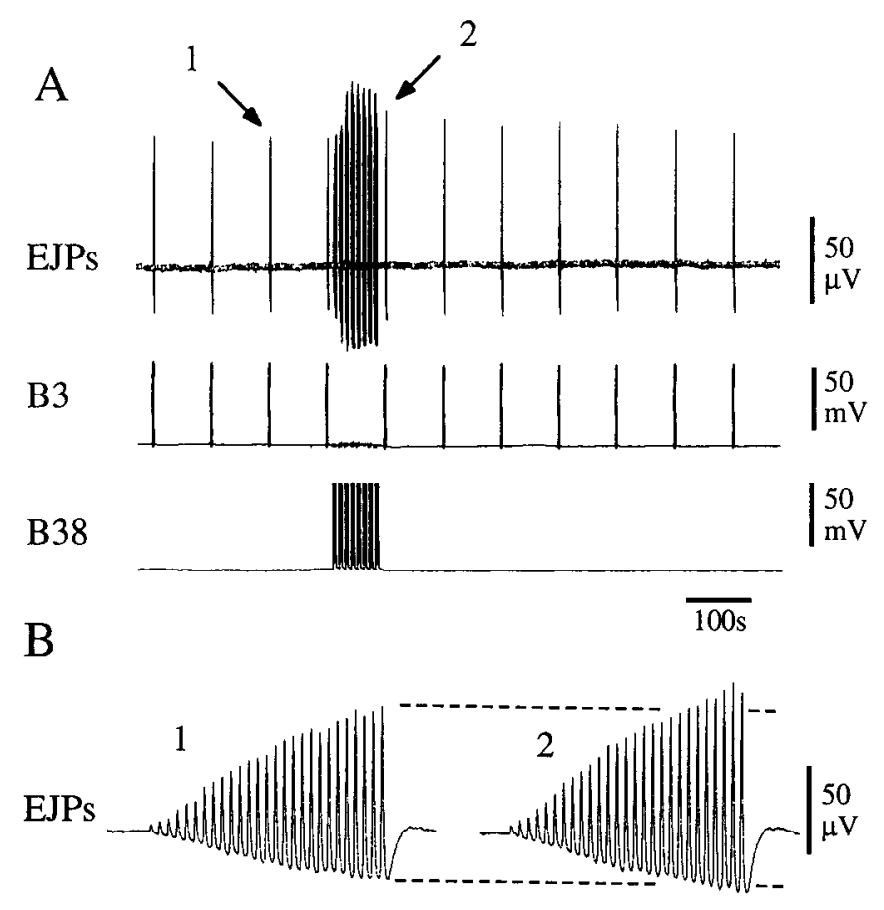

B3

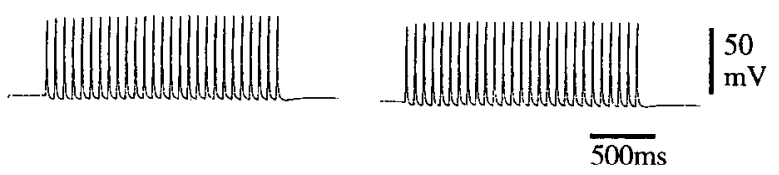

Figure 11. Modulation of B3-evoked EJPs in the I3a muscle by stimulation of B38. The top trace is an extracellular recording of the I3a muscle, the middle trace is an intracellular recording of motor neuron B3, and the bottom trace is an intracellular recording of motor neuron B38. $A$, Stimulation of $\mathrm{B} 3$ at $16 \mathrm{~Hz}$ for $1.6 \mathrm{sec}$ with $100 \mathrm{sec}$ interburst intervals elicited reproducible EJPs in the I3a muscle. B38 was stimulated $(15 \mathrm{~Hz}$ for $4 \mathrm{sec}$ with a $6 \mathrm{sec}$ interburst interval for $80 \mathrm{sec}) 10$ sec into a B3 interburst interval. The subsequent B3-evoked EJPs were increased in amplitude $(15 \pm 2 \%, \pm \mathrm{SD}, n=6)$. $B$, Examination of $\mathrm{B} 3$ evoked EJPs with an expanded time scale before (l) and after (2) stimulation of $\mathbf{B} 38$.

precursor. An SCP precursor encodes single copies of $\mathrm{SCP}_{\mathrm{A}}$ and $\mathrm{SCP}_{\mathrm{B}}$ and also contains additional potential cleavage sites (Mahon et al., 1985). An FMRFamide precursor encodes for multiple copies of FMRFamide, but also contains additional regions that may be processed into peptides with no sequence similarity to FMRFamide (Taussig and Scheller, 1986). Finally, a precursor for the myomodulins encodes multiple copies of Mma and six myomodulin-related peptides including Mmb (Miller et al., 1991).

Aplysia buccal muscles are innervated by a few motor neurons that innervate overlapping populations of fibers. In addition, muscle fibers in the Aplysia buccal mass are nonspiking, and it has been shown that above a threshold value, the strength of contraction of these muscles is very steeply dependent on the integrated area of the compound EJPs (Cohen et al., 1978). Therefore, we used B3-evoked EJPs and muscle contractions as a means to examine the interactions between conventional and peptide cotransmitters in this neuromuscular preparation.

At low concentrations $\left(10^{-8} \mathbf{M}\right)$, the SCPs, FMRFamide, and Mma all increased the amplitude of B3-evoked EJPs and muscle contractions. At higher concentration $\left(10^{-6} \mathrm{M}\right)$, the SCPs and FMRFamide produced a larger increase in EJP amplitude and
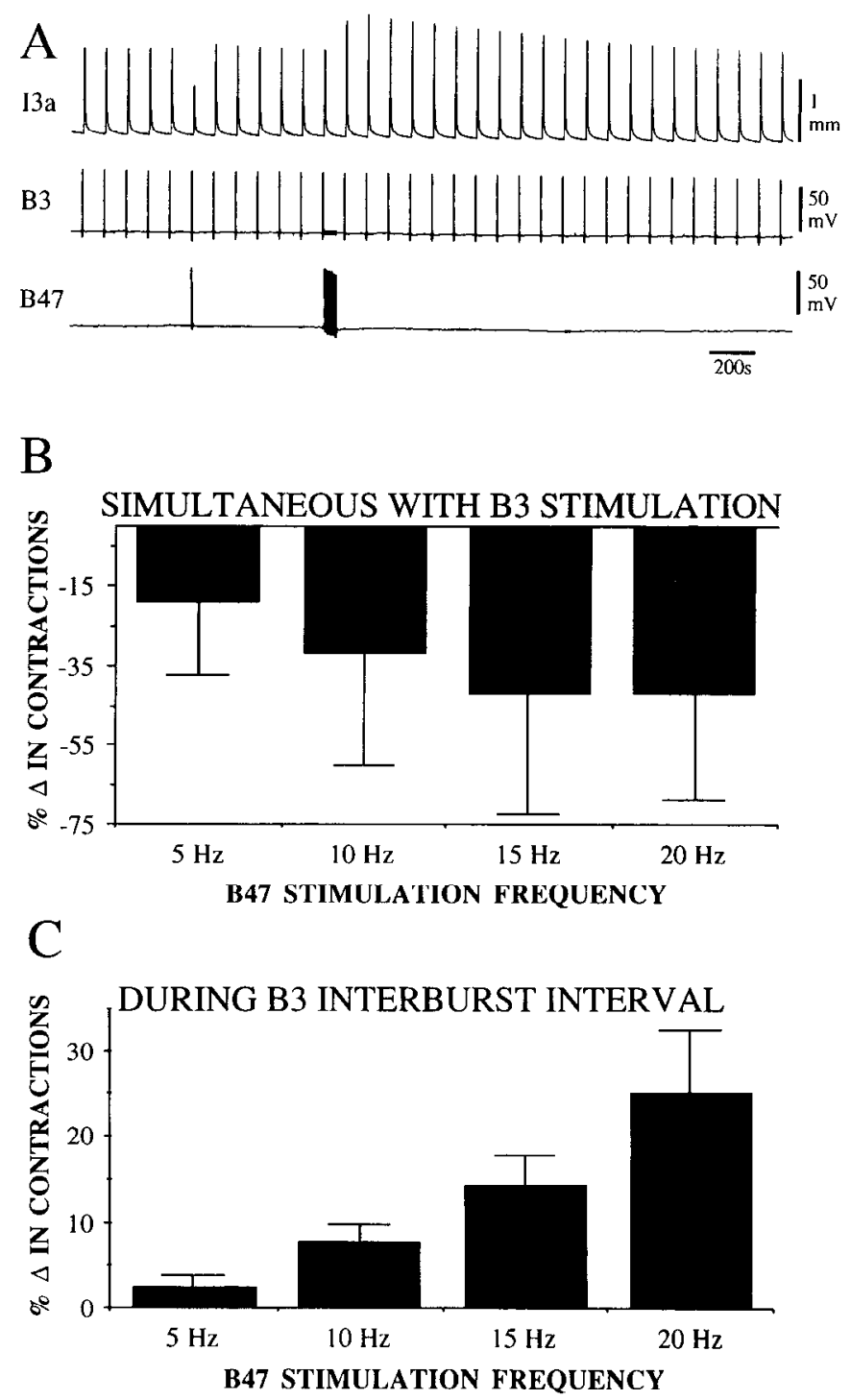

Figure 12. Modulation of B3-evoked I3a muscle contractions by stimulation of $\mathrm{B} 47$. $A$, The top trace is a recording of contractions in the I3a muscle, the middle trace is an intracellular recording from $\mathrm{B} 3$, and the bottom trace is an intracellular recording from B47. Stimulation of $\mathrm{B} 3$ at $16 \mathrm{~Hz}$ for $1.6 \mathrm{sec}$ with $100 \mathrm{sec}$ interburst intervals elicited reproducible I3a muscle contractions. B47 was stimulated $(20 \mathrm{~Hz}$ for $1.6 \mathrm{sec})$ simultaneously with the sixth B3 burst. The corresponding B3-evoked contraction was reduced in amplitude. Subsequent B3-evoked muscle contractions returned to control amplitude. Next, B47 was stimulated $(20 \mathrm{~Hz}$ for $4 \mathrm{sec}$ with a $6 \mathrm{sec}$ interburst interval for $60 \mathrm{sec}) 10 \mathrm{sec}$ into a B3 interburst interval. Subsequent B3-evoked I3a muscle contractions were increased in amplitude. Capacitive coupling from the current electrode in B38 is apparent in the B3 voltage record. $B$, Summary of the effects of stimulating B47 simultaneously with B3 on B3-evoked contractions. B3 was stimulated as above and B47 was stimulated simultaneously with B3 at the indicated frequencies. Percentage changes in B3-evoked contractions are expressed as mean $\pm \mathrm{SD}(n=4)$. $C$, Summary of the effects of stimulating B47 during B3 interburst interval on B3-evoked contractions. B47 was stimulated at the indicated frequencies in $4 \mathrm{sec}$ bursts with $6 \mathrm{sec}$ interburst intervals for $60 \mathrm{sec}$ during B3 interburst interval. Percentage changes in B3-evoked contractions are cxpressed as mean $\pm \operatorname{SEM}(n=4)$.

contractions. Mma also produced a larger increase in EJP amplitude at $10^{-6} \mathrm{M}$ concentrations, but inhibited contractions. It is our interpretation that these changes in EJP amplitude contribute to the modulation of the B3-evoked I3a muscle con- 


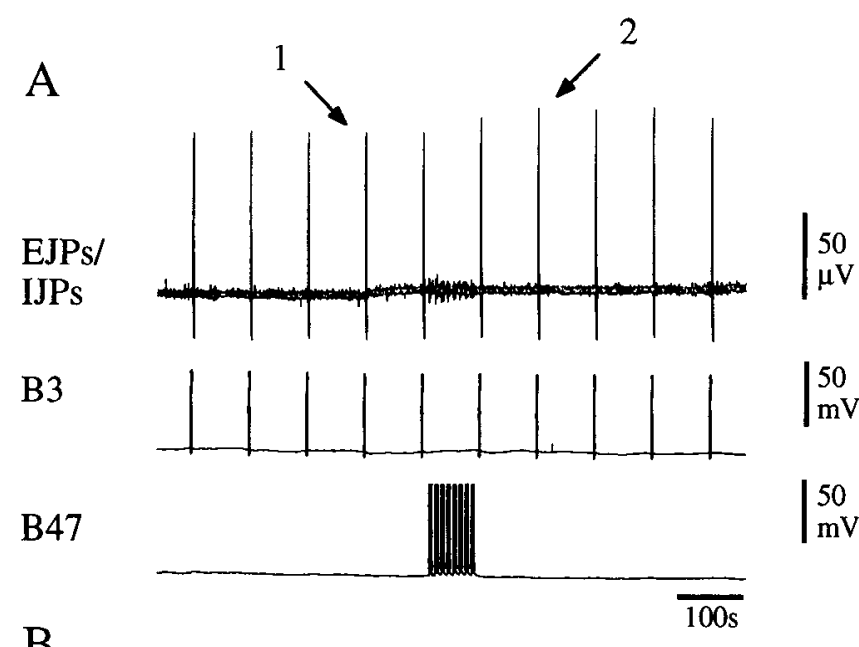

B

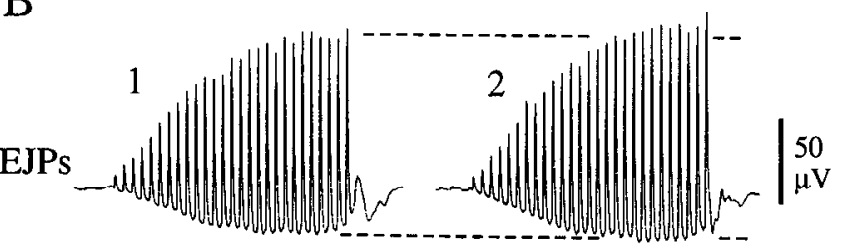

B3

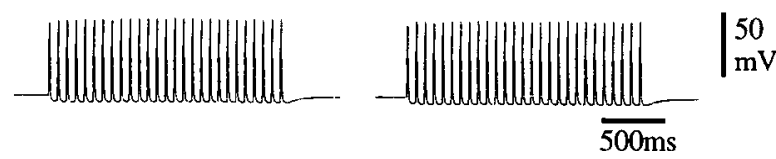

Figure 13. Modulation of B3-evoked EJPs in the I3a muscle by stimulation of B47. The top trace is an extracellular recording of the 13a muscle, the middle trace is an intracellular recording of $\mathrm{B} 3$, and the bottom trace is an intracellular recording of B47. A, Stimulation of B3 at $16 \mathrm{~Hz}$ for $1.6 \mathrm{sec}$ with $100 \mathrm{sec}$ interburst intervals elicited reproducible EJPs in the I3a muscle. B47 was stimulated $(15 \mathrm{~Hz}$ for $4 \mathrm{sec}$ with a 6 sec interburst interval for $80 \mathrm{sec}) 10 \mathrm{sec}$ into a B3 interburst interval The subsequent B3-evoked EJPs were increased in amplitude (11 \pm $2 \%, \pm \mathrm{SD}, n=5$ ). $B$, Examination of B3-evoked EJPs with an expanded time scale before (I) and after (2) stimulation of B47.

tractions produced by these peptides. However, especially in light of the fact that high concentrations of Mma enhance B3evoked EJP amplitude but reduce B3-evoked contractions, it is likely that these peptides also act at other components of the excitation-contraction coupling mechanism, as has been observed for the I5 muscle (Weiss et al., 1978; Brezina et al., 1992).

Since we had shown that the peptides synthesized by I3a motor neurons could be released from cells grown in culture and that exogenous application of those peptides resulted in a marked modulation of evoked EJPs and muscle contractions, we decided to examine whether release of both peptide and conventional transmitters had physiological consequences in the isolated neuromuscular preparation. To do this we examined the effects of stimulating the other I3a motor neurons on B3evoked contractions. When stimulated simultaneously with B3, B47 inhibits the B3-evoked contractions. This inhibition requires that there be temporal overlap of B3 and B47 bursts. Thus, it is likely that this effect is mediated by a direct effect on a conductance rather than via a second messenger system. B47 was determined to be cholinergic and it appears that this direct effect is mediated by ACh. It is our interpretation that this inhibition of the B3-evoked contractions is due to the B47-

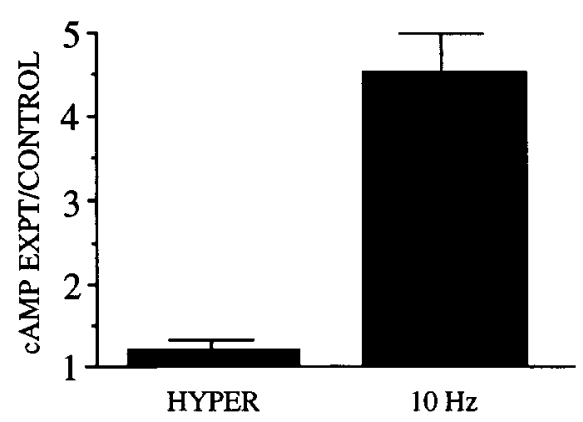

Figure 14. Effects of stimulating motor neuron B38 on cAMP levels in 13a muscle. cAMP normalized to protein of experimental muscle (Expt) was compared to that of the contralateral control muscle from the same animal. B38 was held hyperpolarized $10 \mathrm{mV}$ below resting potential or stimulated at $10 \mathrm{~Hz}$ for $4 \mathrm{sec}$ with $6 \mathrm{sec}$ interburst intervals for $10 \mathrm{~min}$. Values expressed as mean $\pm \operatorname{SEM}(n=4)$. B38 stimulation leads to a significant increase in cAMP levels in 13a.

evoked cholinergic IJPs decreasing the amplitude of the B3evoked EJPs in I3a muscle fibers.

When B47 was stimulated, using a paradigm designed to release peptide cotransmitters, during a B3 interburst interval, the amplitudes of subsequent B3-evoked EJPs and contractions were increased. We suggest that this reversible enhancement is due at least in part to release of the myomodulins from B47 terminals. Superfusion of the I3a neuromuscular preparation with ACh had very little effect on the amplitude of B3-evoked EJPs or contractions. Although in these experiments it is difficult to be sure that $\mathrm{ACh}$ has access to synaptic receptors, these results do suggest that the long-term effects of B47 stimulation are unlikely to be due solely to $\mathrm{ACh}$ release. High concentrations of Mma $\left(\sim 10^{-6} \mathrm{M}\right)$ inhibit B3-evoked contractions. Although we increased B47 stimulation frequency and burst duration in an attempt to maximize peptide release, we were unable to inhibit subsequent contractions. Rather, the level of modulation of evoked EJPs and contractions by stimulation-dependent release of peptides from B3, B38, and B47 more closely resembled the modulation observed by superfusion of $10^{-8} \mathrm{M}$ of the corresponding synthetic peptides. We therefore suggest that the concentration of neuronally released peptides near the receptors with our stimulation paradigms is probably about $10^{-8} \mathbf{M}$.

Similar interactions of the two excitatory motor neurons were also analyzed. As expected, simultaneous stimulation of these motor neurons simply produced a larger contraction. In most experiments, B38 was stimulated in repeated long-duration bursts during the B3 interburst interval. This led to a long-term increase in B3-evoked EJPs and contractions. The amplitude of these effects was dependent on the frequency of stimulation of B38. In a few experiments, the pattern of stimulation of the two neurons was reversed. A frequency-dependent increase in the amplitude of B38-evoked EJPs and contractions was observed. We believe that these modulatory effects are likely due, at least in part, to the release of the SCPs from B38 terminals, or FMRFamide from the B3 terminals in the I3a muscle. The possibility that the enhancement is due simply to some aspect of the contractions evoked by the repeated bursts of the excitatory motor neuron is unlikely because B47 had similar modulatory effects but evoked no contractions (see also Whim and Lloyd, 1990).

It has been previously shown in buccal muscle I5 that the elevation of cAMP could be used as an indirect measurement 
for the release of the SCPs (Whim and Lloyd, 1989). Exogenously applied $\mathrm{SCP} \mathrm{P}_{\mathrm{B}}$ also increases cAMP levels in the I3a muscle (Lotshaw and Lloyd, 1990). We determined that stimulation of B38 also increascd cAMP levels in the muscle, while stimulation of B3 did not have a significant effect on cAMP levels. These findings, combined with the results described above, suggest strongly that sustained high-frequency bursts in B38 lead to the release of SCPs from its terminals.

In conclusion, we have developed a neuromuscular preparation amenable to the study of heterosynaptic modulation involving conventional and peptide transmitters. Our results suggest that these motor neurons can function in two states: when stimulated in single short bursts, they predominantly release conventional transmitters; when stimulated in a series of prolonged bursts, they release both conventional transmitters and peptide cotransmitters. This dual function is most dramatic in the case of B47, which appears to utilize its conventional transmitter, $A C h$, in its role as an inhibitory motor neuron and its peptide cotransmitters, including the myomodulins, in its role as an cxcitatory modulatory motor neuron at the same neuromuscular synapse. To our knowledge, this is the first description of an identified motor neuron that, depending on the stimulation paradigm, can selectively act to inhibit or enhance the effects of a second motor neuron at the same neuromuscular junction. Along with the demonstration of release of the SCPs from B15, the present study indicates that in the buccal neuromuscular system of Aplysia, heterosynaptic facilitation by neuropeptides has important physiological consequences.

\section{References}

Ascher P, Kehoe JS (1975) Amine and amino acid receptors in gastropod neurons. In: Handbook of psychopharmacology (Iverson LL, Iverson SD, Snyder SH, eds), pp 265-310. New York: Plenum.

Banks FW (1975) Inhibitory transmission at a molluscan neuromuscular junction. J Neurobiol 6:429-433.

Bartfai T, Ivereldt K, Fisone G, Serfozo P (1988) Regulation of the release of coexisting transmitters. Annu Rev Pharmacol Toxicol 28: 285-310.

Bishop CA, Wine JJ, Nagy F, O'Shea MR (1987) Physiological consequences of a peptide cotransmitter in a crayfish nerve-muscle preparation. J Neurosci 7:1769-1779.

Brezina V, Cropper EC, Evans CG, Kupfermann I, Weiss KR (1992) Enhancement of $\mathrm{Ca}$ and $\mathrm{K}$ currents by modulating peptide cotransmitters correlated with potentiation and depression of contractions of the ARC muscle in Aplysia. Soc Neurosci Abstr 18:586.

Calabrese RL (1989) Modulation of muscle and neuromuscular junctions in invertebrates. Semin Neurosci 1:25-34.

Carew TJ, Pinsker H, Runinson K, Kandel ER (1974) Physiological and biochemical properties of neuromuscular transmission between identified motoneurons and gill muscle in Aplysia. J Neurophysiol 37:1020-1040.

Church PJ, Lloyd PE (1991a) Expression of diverse neuropeptide cotransmitters by identified motor neurons in Aplysia. J Neurosci 11: 618-625.

Church PJ, Lloyd PE (1991b) Modulation of neuromuscular efficacy by excitatory and inhibitory motor neurons in Aplysia. Soc Neurosci Abstr 17:1306.

Church PJ, Cohen KP, Scott ML, Kirk MD (1991) Peptidergic motoneurons in the buccal ganglia of Aplysia californica: immunocytochemical, morphological, and physiological characterizations. J Comp Physiol [A] 168:323-336.

Cohen JL, Weiss KR, Kupfermann I (1978) Molor control of buccal muscles in Aplysia. J Neurophysiol 41:157-180.

Cropper EC, Lloyd PE, Reed W, Tenenbaum R, Kupfermann I, Weiss KR (1987a) Multiple neuropeptides in cholinergic motor neurons of Aplysia: evidence for modulation intrinsic to the motor circuit. Proc Natl Acad Sci USA 84:3486-3490.

Cropper EC, Tenenbaum R, Gawinowicz Kolks MA, Kupfermann I,
Weiss KR (1987b) Myomodulin: a bioactive neuropeptide present in an identified cholinergic buccal motor neuron of Aplysia. Proc Natl Acad Sci USA 84:5483-5486.

Cropper EC, Miller MW, Tenenbaum R, Gawinowicz Kolks MA, Kupfermann I, Weiss KR (1988) Structure and action of buccalin A: a modulatory neuropeptide localized to an identified small cardioactive peptide-containing cholinergic motor neuron of Aplysia californica. Proc Natl Acad Sci USA 85:6177-6181.

Cropper EC, Price D, Tenenbaum R, Kupfermann I, Weiss KR (1990) Release of peptide cotransmitters from a cholinergic neuron under physiological conditions. Proc Natl Acad Sci USA 87:933-937.

Eisenstadt M, Goldman JE, Kandel ER, Koike H, Koester J, Schwartz JH (1973) Intrasomatic injection of radioactive precursors for studying transmitter synthesis in identified neurons of Aplysia californica. Proc Natl Acad Sci USA 70:3371-3375.

Gardner D (1971) Bilateral symmetry and interneuronal organization in the buccal ganglia of Aplysia. Science 173:550-553.

Gardner D, Kandel ER (1977) Physiological and kinetic properties of cholinergic receptors activated by multiaction interneurons in buccal ganglia of Aplysia. J Neurophysiol 40:333-348.

Hall JD, Lloyd PE (1991) Release of pedal peptide from Aplysia neurons in primary culture. J Neurobiol 22:583-589.

Hokfelt TO, Millhorn D, Seroogy K, Tsuruo Y, Ceccatelli S, Lindh B, Meister B, Melander T, Schalling M, Bartfai T, Terenius L (1987) Coexistence of peptides with classical neurotransmitters. Experimentia 43:768-780.

Howclls HH (1942) The structure and function of the alimentary canal of Aplysia punctata. Q J Microsc Sci 83:357-397.

Kupfermann I (1974) Feeding behavior in Aplysia: a simple system for the study of motivation. Behav Biol 10:1-26.

Kupfermann I (1991) Functional studies of cotransmission. Physiol Rev 71:683-732.

Kupfermann I, Cropper EC, Miller MW, Alevizos A, Tenenbaum R, Weiss KR (1988) Buccalin A: distribution of immunoreactivity in the Aplysia nervous system and biochemical localization to motor neuron B16. Soc Neurosci Abstr 14:177.

Lloyd PE (1988) Fast axonal transport of modulatory neuropeptides from central ganglia to components of the feeding system in Aplysia. J Neurosci 8:3507-3514.

Lloyd PE, Kupfermann I, Weiss KR (1984) Evidence for parallel actions of a molluscan peptide $\left(\mathrm{SCP}_{\mathrm{B}}\right)$ and serotonin in mediating arousal in Aplysia. Proc Natl Acad Sci USA 81:2934-2937.

Lloyd PE, Kupfermann I, Weiss KR (1987a) The sequence of small cardioactive peptide $\mathrm{A}$ : a second member of a class of neuropeptides in Aplysia. Peptides 8:179-184.

Lloyd PE, Frankfurt M, Stevens P, Kupfermann I, Weiss KR (1987b) Biochemical and immunocytological localization of the neuropeptides FMRFamide, $\mathrm{SCP}_{\mathrm{A}}$ and $\mathrm{SCP}_{\mathrm{B}}$ to neurons involved in the regulation of feeding in Aplysia. J Neurosci 7:1123-1132.

Lotshaw DP, Lloyd PE (1990) Peptidergic and serotonergic facilitation of a neuromuscular synapse in Aplysia. Brain Res 526:81-94.

Mahon AC, Lloyd PE, Weiss KR, Kupfermann I, Scheller RH (1985) The small cardioactive peptides A and B of Aplysia are derived from a common precursor molecule. Proc Natl Acad Sci USA 82:39253929.

Miller MW, Stamm S, Cropper EC, Villim FS, Beushausen S, Brosius J, Kupfermann I, Weiss KR (1991) Characterization of a cDNA clone encoding multiple myomodulin-related neuropeptides in Aplysia. Soc Neurosci Abstr 17:1305.

Morris HR, Panico M, Karplus A, Lloyd PE, Riniker B (1982) Elucidation by FAB-MS of the structure of a new cardioactive peptide from Aplysia. Nature 300:643-645.

Mulle C, Benoit P, Pinset C, Roa M, Changeux J-P (1988) Calcitonin gene-related peptide enhances the rate of desensitization of the nicotinic acetylcholine receptor in cultured mouse muscle cells. Proc Natl Acad Sci USA 85:5728-5732.

Nagahama T, Takata M (1990) Innervation of buccal muscles by multifunctional MA1 neurons in Aplysia kurodai. J Comp Physiol A 167:1-10.

New HV, Mudge AW (1986) Calcitonin gene-related peptide regulates muscle acetylcholine receptor synthesis. Nature 323:809-811.

Ono JK, McCaman RE (1980) Identification of additional histaminergic neurons in Aplysia: improvement of single cell isolation techniques for in tandem physiological and chemical studies. Neuroscience 5:835-840. 
O'Shea M, Schaffer M (1985) Neuropeptide function: the invertebrate contribution. Annu Rev Neurosci 8:171-198.

Price DA, Greenberg MJ (1977) Structure of a molluscan cardioexcitatory neuropeptide. Science 197:670-671.

Sawada M, Blankenship JE, McAdoo DJ (1981) Neural control of a molluscan blood vessel, anterior aorta of Aplysia. J Neurophysiol 46: 967-986.

Schacher S, Proshansky E (1983) Neurite regeneration by Aplysia neurons in dissociated cell culture: modulation by Aplysia hemolymph and the presence of the initial axon segment. J Neurosci 3:2403-2413.

Taussig R, Scheller RH (1986) The Aplysia FMRFamide gene encodes sequences related to mammalian brain peptides. DNA 5:453-461.

Villim FS, Cropper EC, Alevizos A, Tenenbaum R, Kupfermann I, Weiss KR (1989) Structure determination and cellular localization of a novel myomodulin related octapeptide in Aplysia. Soc Neurosci Abstr 15:665.
Weiss KR, Cohen JL, Kupfermann I (1978) Modulatory control of buccal musculature by a serotonergic neuron (metacerebral cell) in Aplysia. J Neurophysiol 41:181-203.

Weiss KR, Mandelbaum DE, Schonberg M, Kupfermann I (1979) Modulation of buccal muscle contractility by serotonergic metacerebral cells in Aplysia: evidence for a role of cyclic adenosine monophosphate. J Neurophysiol 42:791-803.

Whim MD, Lloyd PE (1989) Frequency-dependent release of peptide cotransmitters from identified cholinergic motor neurons in Aplysia. Proc Natl Acad Sci USA 86:9034-9038.

Whim MD, Lloyd PE (1990) Neuropeptide cotransmitters released from an identified cholinergic motor neuron modulate neuromuscular efficacy in Aplysia. J Neurosci 10:3313-3322.

Whim MD, Lloyd PE (1992) Modulation of peptide release from single identified Aplysia neurons in culture. J Neurosci 12:3545-3553. 